\title{
The Difference of Academic Procrastination between Students Who Are Active and Not Active in Organizations Student Activity Units in the Faculty of Psychology, University of Medan Area
}

\author{
Babby Hasmayni \\ Faculty of Psychology, University of Medan Area, Indonesia \\ Email: babby@staff.uma.ac.id
}

\begin{abstract}
This study aims to determine the differences in academic procrastination between active and non-active students in student organizations in the Faculty of Psychology, University of Medan Area. The scale of academic procrastination in this study is based on the characteristics of academic procrastination according to Ferrari, Johnson, and McCown. The results shows that There is no difference in academic procrastination between students who are active and not active in participating the organizational activities by looking at the value or coefficient of difference in anava $F=0.200$ with $P>0.05$. There is significant differences in academic procrastination between male and female students. These results are known by looking at the value or coefficient of difference in anava $F=14.137$ with $P<0.010$. Calculation results from the comparison of empirical mean and hypothetical mean of academic procrastination $(112.5<149.2368)$, where the empirical mean of academic procrastination is greater than the hypothetical mean, it can be stated that the academic procrastination of students is high.
\end{abstract}

Keywords: academic procrastination; students; organizations

\section{Introduction}

Academic procrastination conducted by students occurs in many universities. Solomon \& Rothblum (in Holmes, 2000) mentioned that the students who did the most procrastination in writing assignments were $46 \%$. In addition, in reading assignments $30.1 \%$, studying for exams $27.6 \%$, attending meetings (lectures) $23 \%$ in administrative tasks $10.6 \%$ and overall academic performance $10.2 \%$. Some research that supports this is Ellis and Knaus's research (in Holmes, 2000) which reported $70 \%$ of American students doing procrastination. Solomon and Rothblum also examined the same thing with 291 American students by getting more specific results in which more than $40 \%$ of participants always procrastinated in writing assignments (Holmes, 2000).

Not only due to low self-control, can differences in procrastination also be seen from differences in sex. The results of Lidya's research (2008) empirically prove that subjects with male sex have a tendency for higher academic procrastination compared to subjects with female sex. This is because subjects with male sex have other orientations besides doing academic tasks which make it difficult for them to focus on one thing compared to subjects with female sex who are more easily focused on one particular thing. However, the results of a Ferrari (1995) study found that the level of father's authoritarian parenting led to the emergence of chronic procrastination behavioral tendencies on the subject of girls' studies, while the level of authoritarian parenting produced girls who were not procrastinators. But mothers who have a tendency to procrastinate produce girls who have a tendency to procrastinate too.

Student organization is one of the factors causing students to carry out academic procrastination. According to As'ari (2007), there are two forms of student organizations, namely 
intra-campus organizations and extra-campus organizations. Intra-campus organization, which is an organization within the campus, whose scope of activities is limited to students who are on campus or at any time involve external participants. This intra organization is divided into two parts, namely first, based on the scope of which consists of department-level organizations (the scope of which is one department), Faculty-level organizations (the scope is one faculty) and University-level organizations (university-level scope). Second, organizations based on interests and talents or better known as Student Activity Units (UKM) with the scope of which are at the Faculty level and more at the University level. Extra-campus organizations are organizations that are outside the campus, where the scope and members are students of college or cross-university level.

University of Medan Area also has two forms of student organizations, namely intracampus organizations and extra-campus organizations. In this study, researchers focus on intracampus organization based on the scope of one Faculty or also called Faculty-level organizations. Faculty level organizations at University of Medan Area are called Student Activity Units (UKM) which have many activities, so that their members consisting of several sections have a dense organizational activity in accordance with their work program.

\section{Review of Literature}

\subsection{Definition of Procrastination}

The term procrastination comes from the Latin procrastination with the prefix "pro" which means pushing forward or moving forward and the suffix "crastinus" which means the decision of tomorrow. If combined, it becomes "suspend" or "delay until the next day". (Gufron and Rini, 2010).

Delays or avoidance of tasks which are then called procrastination are not always interpreted the same in perspective in human culture. For example, the ancient Egyptians interpreted procrastination into two meanings, namely showing something useful to avoid important work and impulsive effort. It also shows the meaning of harmful habits due to laziness in completing a task that is important for a living, such as working the fields when planting time has arrived. So in the past century, procrastination has a positive meaning when delaying as a constructive effort to avoid impulsive decisions, without careful thought, and negative meaning when done because of laziness or without definite goals (Gufron and Rini, 2010).

In scientists, the term procrastination is used to indicate a tendency to delay the completion of a task or job. Someone has a tendency to postpone or not immediately start work, when facing a job and task is called someone who does procrastination. It doesn't matter whether the delay has a reason or not. Every delay in dealing with a task is called procrastination (Ghufron and Rini, 2010).

According to Glenn (2002) procrastination is associated with various psychiatric syndromes. A procrastinator usually also has unhealthy sleep patterns, has chronic depression, causes stress, and other causes of psychological disorders. Besides procrastination also has a paradoxical relationship to guidance and counseling.

\subsection{Definition of Students}

Students are those who are registered and are attending education in tertiary institutions (PT), both state and private tertiary institutions. The purpose of education in higher education is so that students can master knowledge and skills in accordance with their fields, and make 
students become mature and intellectual people so that they can play a role and assume responsibility in social life. Students are college level students and mature emotional, psychological, physical, independence development, have developed into adults. Sukirman (in Hulu, 2010)

Students are people who study in tertiary institutions, whether in universities, institutions or academies. Those who are enrolled in tertiary institutions can be referred to as students. The period of students covers the age range 18/19 years to 20/21 years, namely students from semester I to semester IV, and periods $21 / 22$ years to $24 / 25$ years, namely students in semester V up to semester VIII (Winkel, 1997).

According to Piaget (in Hulu, 2010), the cognitive capacity of individuals aged 18 years has reached formal operations, this level causes individuals to be able to solve complex problems with the capacity to think abstractly, logically, and rationally. In terms of intellect, most of them have graduated from high school and entered college.

\subsection{Differences of Academic Procrastination between Students Who Are Active and Not Active in Participating the Student Organizations}

According to Knaus (in Ahmaini, 2010), procrastination can affect students' academic and personal success. If the habit of procrastinating arises constantly on students, it will certainly have a negative impact on academic life. According to him, procrastination can affect achievement and cause a low Achievement index (IP). However, this does not indicate that students with good performance will not delay.

Campus life is always colored with a variety of views about the obligations that must be taken and carried out by students. This is related to the existing legitimacy in social life that is, a student must carry out his obligations to study. This makes the orientation of the lecture a major obligation in student life, but in the midst of the main obligations that exist, there are students who do things outside the legitimacy that is, by participating in organizational activities. Organizational orientation then becomes an inseparable part in lecture activities because students not only focus on college obligations but also organizational activities become an equally important concern (Sentosa, 2008).

Campus organizations are often associated with activists, and conversely activists must be linked to campus organizations. Activists are also often portrayed as students who are actively organizing but have low GPA (low Achievement Achievement Index), while non-activist students are often portrayed as students who always have good GPA, above average, but who have no concern with things outside of academia (Sentosa, 2008).

There is also an opinion from the Indonesian Welfare Education Forum (2007) that those who are in college, and are active in organizations, can actually manage their time well. Every time is useful and does not waste the accuracy that is there. When compared with people who are not involved in an organization, the time is only for college. Not a few students who are involved in organizations can instead quickly graduate because these students can divide their time and not let the time spent wasted without being filled with meaningful activities and many of them even more enthusiastic and diligent in learning. 


\section{Research Method}

The research method determines a research because it involves the right way in data collection, data analysis and decision making of research results (Hadi, 2000).

Identification of Research Variables

1. Dependent variable : Academic Procrastination

2. Independent variable : Activities in Student Organizations
a. Active in organization

b. Not actively organized

3. Moderator variables : Gender
a. Male
b. Girl

The scale of academic procrastination in this study is based on the characteristics of academic procrastination according to Ferrari, Johnson, and McCown (in Gufron and Rini, 2010), namely: (a) delay in starting and completing assignments, (b) delays in doing assignments, ( c) the time gap between plans and actual performance, and (d) carrying out more enjoyable activities. In filling this scale, the sample is asked to answer the existing questions by choosing one of the answers from the available alternative answers. On this scale given 4 (four) alternative answers, namely Very Appropriate (SS), Appropriate (S), Unsuitable (TS) and Inappropriate (STS). Statements on this scale consist of favorable and unfavorable statements. Favorable items, Very Appropriate answers will be given a score of 4, appropriate answers are given a score of 3, Unsuitable answers are given a score of 2, and inappropriate answer will be given a score of 1 . An unfavorable item, each Very Appropriate answer will be given a score of 1, Appropriate answers was given a score of 2 , the answer that was unsuitable was given a score of 3 , and the answer which was inappropriate was given a score of 4 .

The technique used to test the validity of measuring instruments, in this case the validity of the questionnaire was tested using the Product Moment analysis technique of Pearson rough numbers formula, which is to find the correlation coefficient between each item with a total score (Hadi, 2004).

Where the formula is:

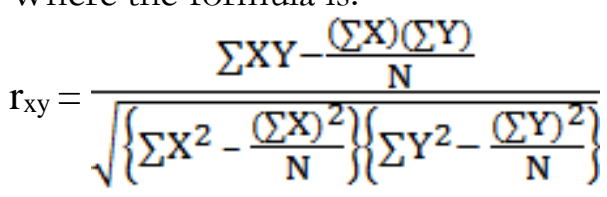

Information:

rxy $=$ correlation coefficient between each item with a total score.

$\mathrm{XY}=$ Number of times between each item with a total score.

$\mathrm{X}=$ Total score of the whole subject for each item.

$\mathrm{Y}=$ Total score of all items in the subject.

$\mathrm{X}=$ Number of squares of score $\mathrm{x}$

$\mathrm{Y} \quad=$ Number of squares score $\mathrm{y}$

$\mathrm{N} \quad=$ Number of subjects.

Testing the power of item discrimination requires computational correlation coefficients between the distributions of item scores with a relevant criterion namely the distribution of the scale scores themselves. This computation produces the total item correlation coefficient (rix), also known as the item power difference parameter. For scales where each item is scored on an 
internal level, the Pearson product moment correlation coefficient formula can be used. This testing procedure uses a significance level of 5\% ( $p>0.05$ ). According to Ebel (in Azwar, 2006), the criteria for evaluating item discrimination index, which is a value of $\geq 0.3$, is considered good although it may still be improved.

This study aims to determine the differences in academic procrastination between active and non-active students in student organizations. Statistical analysis is used to show conclusions and because statistics work with numbers, statistics are objective, and statistics are universal (Hadi, 2000). However, data analysis in this study uses the Anava A - B. Anava A - B technique is a research analysis technique with a two-factor factorial design (Arikunto, 2007).

Table 1. The design of this study

\begin{tabular}{|c|c|c|c|}
\hline \multirow{2}{*}{\multicolumn{2}{|c|}{ Subject $\quad$ Variable }} & \multicolumn{2}{|c|}{$\mathbf{A}$} \\
\hline & & Active & Non Active \\
\hline \multirow{2}{*}{ B } & Male & & \\
\hline & Female & & \\
\hline
\end{tabular}

\section{Discussion}

\subsection{Result}

Table 2. Distribution of Items of Academic Procrastination Statement Distribution before Trial

\begin{tabular}{|l|l|c|c|l|}
\hline \multirow{2}{*}{ No } & \multirow{2}{*}{$\begin{array}{c}\text { The Characteristics of } \\
\text { Academic Procrastination }\end{array}$} & \multicolumn{2}{|c|}{ Number of Items } & \multirow{2}{*}{ Total } \\
\cline { 3 - 4 } 1 & $\begin{array}{l}\text { Delay to start and complete } \\
\text { tasks }\end{array}$ & $1,4,9,10,25,30,45,46$ & $11,12,21,35,38,50,54$ & \multirow{2}{*}{14} \\
\hline 2 & Delay in doing the task & $2,14,20,22,31,36,55$ & $3,23,33,39,47,51$ & 14 \\
\hline 3 & $\begin{array}{l}\text { The time gap between and } \\
\text { actual performance }\end{array}$ & $5,6,13,19,26,32,40$ & $8,27,29,37,41,44,52$ & 14 \\
\hline 4 & Do more fun activities & $7,15,24,28,43,48,53$ & $16,17,18,34,42,49,56$ & 14 \\
\hline & Total & $\mathbf{2 8}$ & $\mathbf{2 8}$ & $\mathbf{5 6}$ \\
\hline
\end{tabular}

The scale of procrastination in this study uses a Likert scale with 4 alternative answers containing statements obtained from the answers of subjects who state support (favorable) or not support (unfavorable). The rating of favorite items moves from the value of four (4) for the answer "Strongly Agree (SS)", indigo three (3) for the answer "Agree (S)", value two (2) for the answer "Disagree (TS)", and value of one (1) for the answer "Strongly Disagree (STS)". Rating unfavorable items move from value four (4) for the answer "Strongly Disagree (STS)", value three (3) for the answer "Disagree (TS)", value two (2) for the answer "Agree (S)", and a value of one (1) for the "Strongly Agree (SS)" answer.

Based on the results of the academic scale procrastination trial totaling 56 items, it is known that there are 11 items that failed and 45 items were valid. Eleven items that fall are items number $5,8,11,27,29,35,38,47,48,55$, and 56 . Eleven items that fall have different power coefficients $\mathrm{p}<0.300$, so there are 45 non-knocked items, with different coefficients of moving power from rxy $=0.300$ to $\mathrm{rxy}=0.767$.

The following table is the distribution of interpersonal communication scale items after being tested. 
Vol. 2, No. 1, March 2020, Page: 411-421

Table 3. Distribution of Items of Academic Procrastination Scale Statement Items after the Trial

\begin{tabular}{|c|c|c|c|c|c|c|}
\hline \multirow[t]{3}{*}{ No } & \multirow{3}{*}{$\begin{array}{c}\text { The Characteristics } \\
\text { of Academic } \\
\text { Procrastination }\end{array}$} & \multicolumn{4}{|c|}{ Number of Items } & \multirow[t]{3}{*}{ Total } \\
\hline & & \multicolumn{2}{|c|}{ Favorable } & \multicolumn{2}{|c|}{ Unfavorable } & \\
\hline & & Valid & Invalid & Valid & Invalid & \\
\hline 1 & $\begin{array}{l}\text { Delay to start and } \\
\text { complete tasks }\end{array}$ & $1,4,9,10,25,30,45,46$ & - & $12,21,50,54$ & $11,38,35$ & 15 \\
\hline 2 & $\begin{array}{l}\text { Delay in doing the } \\
\text { task }\end{array}$ & $2,14,20,22,1,36$ & 55 & $3,23,33,39,51$ & 47 & 13 \\
\hline 3 & $\begin{array}{l}\text { The time gap between } \\
\text { and actual } \\
\text { performance }\end{array}$ & $6,13,19,26,32,40$ & 5 & $37,41,44,52$ & $8,27,29$ & 14 \\
\hline 4 & $\begin{array}{l}\text { Do more fun } \\
\text { activities }\end{array}$ & $7,15,24,28,43,53$ & 48 & $\begin{array}{l}16,17,18,34,42, \\
49\end{array}$ & 56 & 13 \\
\hline & Total & 26 & 3 & 19 & 8 & 56 \\
\hline
\end{tabular}

After the items were analyzed the reliability index obtained at rxy $=0.944$ thus it can be said that this measurement tool is reliable.

The research was carried out on September 14-16, 2011. At that time the scale distributed to students who were active and who were not actively participating in the activities of UKM organizations at the University of Medan Area was 76 copies. Where the 38 copies were distributed to members who were active in the organization, and the remaining 38 copies were distributed to members who were not active. In the field implementation, the researcher was assisted by 1 friend. The study was conducted after first conducting trials with different samples.

The first stage of data collection took place on September 14, 2011, beginning with the researcher along with 1 friend coming to the room where the members of the organization were gathering, then giving an explanation of the intent and purpose of spreading the scale. After getting approval to fill the scale from the members of the organization, the researcher first explains the procedure for filling the scale by only giving a check mark $(\sqrt{ })$ to each statement that is in accordance with each of them. Then the researcher invites the subject to fill the scale that has been previously shared. Of the 38 scale copies distributed, all returned.

After all the scales distributed have been collected according to the number of research samples then the researcher withdraws to go home immediately, not forgetting the researchers to thank all members of the organization who helped researchers provide data and have filled out the scale given by researchers for the needs of the research sample.

Then on September 15-16, 2011, researchers conducted data collection for members of the organization who were not actively following the organization's activities. In determining which members are active with those who are not active, researchers rely on professional judgment from the chairman and administrators of the organization. At this stage the researcher had difficulty in meeting the subject because the campus situation at that time was on holiday, so the researcher could not give the scale at once to the subjects. Finally, researchers only provide a scale to the subjects that can be found, then the rest is given tomorrow after researchers promise to meet with the subject. On September 16, 2011 to September 17, 2011, researchers sorted the scale collected. All intact scales are collected and the researcher scores by summing the values obtained by each research subject on each variable. As the independent variable is the Active Student with the Inactive student activity following the student activity unit $(X)$ and the dependent variable is academic procrastination (Y). 
In line with the system used in this study, the data items valid from each scale were taken to be used as research data. The point is that the values of the valid items of each variable are added up again, then after they are known the values are then paired up, where the independent variable As an independent variable is active students with those who are not actively participating in the student activity unit organizational activities $(\mathrm{X})$ and the dependent variable is academic procrastination $(\mathrm{Y})$.

The data analysis method used in this study is the Anava A - B. Anava A - B technique is a research analysis technique with a two-factor factorial design. But before the data were analyzed using the Anava A-B technique, the assumptions test of the variable at the center of attention was first tested, namely academic procrastination which included the test of normality and homogeneity.

This distribution normality test is to prove that the spread of research data that is the center of attention, spreads based on the normal curve principle. The distribution normality test was analyzed using the Skewness-Kurtosis formula. Based on this analysis, it is known that the academic procrastination variable follows the normal curve form. As a criterion if $\mathrm{p}>0.050$ the distribution is declared normal, conversely if $\mathrm{p}<0.050$ the distribution is declared abnormal (Hadi and Pamardiningsih, 2000). The following table summarizes the results of the distribution normality test.

Table 4. The Summary of Calculation Results for the Distribution Normality Test

\begin{tabular}{|l|l|l|l|r|l|}
\hline Variable & Average & K-S & SD & p & Information \\
\hline Academic & 1.492 & -0.191 & 3.0889 & 3.54331 & Normal \\
Procrastination & & 0.305 & & & \\
\hline
\end{tabular}

Information:

$\begin{array}{ll}\text { Average } & : \text { Average } \\ \mathrm{K}-\mathrm{S} & : \text { Kurtosis-Skewness Coefficient } \\ \mathrm{SD} & : \text { Standard deviation } \\ \mathrm{P} & : \text { Opportunity corrections }\end{array}$

From the test results the distribution of normality assumptions is found that the data used in this study meet the normal distribution of data distribution rules, which is shown by the Skewness coefficient $=0.305$ with $\mathrm{p}>0.05$; and Kurtosis coefficient $=-0.191$ with $\mathrm{p}>0.05$.

Homogeneity test is performed to determine whether the population and sample are homogeneous using statistical lavene, where $>0.05$ means the sample is declared homogeneous. In this study, the variance homogeneity test was carried out on two different groups namely academic procrastination based on sex and academic procrastination based on organizational status. The following is a summary of the variant homogeneity test results

Table 5. The Summary of Test Results for Variant Homogeneity by Gender

\begin{tabular}{|l|l|l|l|l|l|}
\hline \multicolumn{1}{|c|}{ Variable } & Homogeneity Test & \multicolumn{1}{c|}{ Source } & $\mathbf{X}$ & $\mathbf{p}$ & Information \\
\hline $\begin{array}{l}\text { Academic } \\
\text { Procrastination }\end{array}$ & Levene statistic & A1 x A2 & 0.036 & 0.849 & Homogeny \\
\hline
\end{tabular}

Information:

A1 : Academic procrastination of male students

A2 : Academic procrastination of female students 
X : The coefficient of homogeneity

P : Opportunity corrections

Homogeneity test results based on sex showed that the data of this study had homogeneous distribution in both male and female groups; as shown by the coefficient of homogeneity of 0.036 with $\mathrm{p}>0.05$

Table 6. The Summary of Test Results for Variant Homogeneity Based on Organizational Status

\begin{tabular}{|l|l|l|c|c|c|}
\hline \multicolumn{1}{|c|}{ Variable } & Homogeneity Test & Source & $\mathbf{X}$ & $\mathbf{p}$ & Information \\
\hline $\begin{array}{l}\text { Academic } \\
\text { Procrastination }\end{array}$ & Levene statistic & A1 x A2 & 0.676 & 0.414 & Homogeny \\
\hline
\end{tabular}

Information:

A1 : Academic procrastination of students who are actively organizing

A2 : Academic procrastination of students who are not actively organizing

$\mathrm{X} \quad$ : The coefficient of homogeneity

$\mathrm{P} \quad$ : Opportunity corrections

Homogeneity test results based on organizational status indicate that the data of this study have homogeneous distribution both to groups of students who are actively organizing and students who are not actively organizing; as shown by the coefficient of homogeneity of 0.676 with $\mathrm{p}>0.05$.

Based on the results of analysis with 2-lane ANOVA, it is known that there is a very significant difference in procrastination between male students and female students, which is indicated by the coefficient $\mathrm{F}=14,137$ with $\mathrm{p}<0.01$. it turns out that women tend to display higher procrastination behavior compared to male students.

While based on the results of 2-channel ANOVA analysis based on organizational status states that there is no difference in procrastination between students who are actively organizing and students who are not actively organizing, as indicated by the coefficient $F=0.200$ with $p>$ 0.05; this means that both students who are active in organizations and who do not have the same level of proclamation tend to be the same.

Table 7. The Summary of the Results of 2-Path Variance Analysis

\begin{tabular}{|c|c|c|c|c|c|}
\hline Academic Procrastination & JK & Df & RK & F & p \\
\hline Based on organizational status & 193.012 & 1 & 193.012 & 0.200 & 0.656 \\
\hline By gender & 11478.368 & 1 & 11478.368 & 14.137 & 0.000 \\
\hline Total & $\mathbf{1 1 6 7 1 . 3 8}$ & $\mathbf{2}$ & $\mathbf{1 1 6 7 1 . 3 8}$ & $\mathbf{1 4 . 3 3 7}$ & $\mathbf{0 . 6 5 6}$ \\
\hline
\end{tabular}

Information:

$\begin{array}{ll}\text { JK } & \text { : Number of squares } \\ \text { RK } & \text { : Average squared } \\ \text { F } & \text { : Coefficient Value } \\ \text { P } & \text { : Opportunity corrections }\end{array}$

The Calculation Results of Hypothetical Mean and Empirical Mean a. Hypothetical Mean.

On the academic procrastination scale the number of valid items is 45 items in the Likert scale format in 4 answer choices, then the hypothetical mean is $\{(45 \times 1)+(45 \times 4)\}: 2=112.5$. 
Empirical means are the average means or averages that are theoretical or actual, which means that the mean refers to the total overall score of subjects that have been obtained divided by a number of subjects. Based on the results of data analysis pliers have been conducted in research, the empirical mean is 149.2368 .

In an effort to find out the difference between active and inactive student academic procrastination, it is necessary to compare the mean / empirical average value with the hypothetical mean / mean value by observing the amount of SB or SD number, in this study the $\mathrm{SB}$ or $\mathrm{SD}$ value of academic procrastination is in the amount of 30.8899 .

From the number of SB or SD academic procrastination, if the mean / average hypothetical value <mean / empirical average value, where the difference exceeds the number one SB / SD, then it is stated that the academic procrastination of students is high and if the mean / average value hypothetical mean / mean / empirical average value, where the difference exceeds the standard deviation / standard deviation, then it is stated that the academic procrastination of students is relatively low.

A full picture of the comparison of mean / hypothetical mean values with empirical mean / mean values can be seen in the table below.

Table 8. The Summary of Calculation Results of Hypothetical Average Score and Empirical Average Score

\begin{tabular}{|c|c|c|c|c|}
\hline \multirow{2}{*}{ Variable } & \multirow{2}{*}{ SB / SD } & \multicolumn{2}{|c|}{ Average value } & \multirow{2}{*}{ Information } \\
\cline { 3 - 4 } & & Hypothetic & Empiric & \\
\hline Academic Procrastination & 30.8899 & 112.5 & 149.2368 & High \\
\hline
\end{tabular}

\subsection{Discussion}

Based on the results of data analysis using the 2-path variance analysis method, it was found that there was no difference in academic procrastination between students who were active and those who were not actively organized. These results are known by looking at the value or coefficient of difference in anava FA-B $=0.200$ with $\mathrm{p}>0.05$. This states that the proposed hypothesis is rejected, which says there is no difference in academic procrastination between active students and those who are not actively participating in the Student Activity Unit organizational activities in the Faculty of Psychology, University of Medan Area. This means that student activity in organizing does not affect academic procrastination. However, this does not mean that active and inactive students have never proclaimed. In addition there are other factors that can influence the occurrence of one's academic procrastination to be higher, for example internal factors and external factors. Internal factors are factors that originate from within the individual such as the individual's physical condition as well as the psychological condition of the individual and external factors, namely factors originating from outside the individual such as parenting style and environmental conditions. This is in line with the opinion of Gufron (2003) which states that the factor within the individual that also influences the emergence of academic procrastination is the physical condition and health condition of the individual, for example fatigue. Someone who is experiencing fatigue will have a higher tendency to procrastinate than those who don't.

Furthermore, from the comparison of empirical mean and hypothetical mean of academic procrastination $(112.5<149.2368)$, where the empirical mean of academic procrastination is 
greater than the hypothetical mean, it can be stated that students' academic procrastination is high. So it can be concluded that the research subject has a high academic procrastination.

While the results of data analysis using the 2-path variance analysis method, the results show that there are significant differences in academic procrastination between male and female students. This result is known by looking at the anava difference value or coefficient $\mathrm{F}=14.137$ with $\mathrm{P}<0.010$. This states that the proposed hypothesis is accepted, which says there are differences in academic procrastination between male students and female students, where female students tend to display higher procrastination behavior compared to male students. This result is contrary to the results of research by Lidya (2008) which says that men are more procrastination than female students.

\section{Conclusion}

There is no difference in academic procrastination between students who are active and not active in participating the organizational activities by looking at the value or coefficient of difference in anava $\mathrm{F}=0.200$ with $\mathrm{P}>0.05$. This states that the proposed hypothesis is rejected, which says there is no difference in academic procrastination between active students and not active in participating the Organizations Student Activity Units at Faculty of Psychology, University of Medan Area.

There is significant differences in academic procrastination between male and female students. These results are known by looking at the value or coefficient of difference in anava $\mathrm{F}$ $=14.137$ with $\mathrm{P}<0.010$. This states that the proposed hypothesis is accepted, which says there is differences in academic procrastination between male students and female students, where female students tend to display higher procrastination behavior compared to male students.

Calculation results from the comparison of empirical mean and hypothetical mean of academic procrastination $(112.5<149.2368)$, where the empirical mean of academic procrastination is greater than the hypothetical mean, it can be stated that the academic procrastination of students is high. So it can be concluded that the research subject has a high academic procrastination.

\section{References}

Ahmaini, D. 2010. Hubungan Antara Keaktifan dalam Organisasi dengan Prokrastinasi Akademik Mahasiswa di Universitas sumatera Utara. Skripsi. (Tidak Diterbitkan). Medan: fakultas Psikologi Universitas Sumatera Utara.

Arikunto, S. 2007. Manajeman Penelitian. Jakarta: Rineka Cipta. 2003. Metode Penelitian. Jakarta: Rineka Cipta.

As'ari, D.K. 2007. Mengenal Mahasiswa dan Seputar Organisasinya. Jakarta: PT Gramedia Pustaka Utama.

Azwar, S. 2006. Pengantar Psikologi inteligensi. Yogyakarta: Pustaka Belajar. . 2004. Penyusunan Skala Psikologi. Yogyakarta: Pustaka Belajar. . 2005. Tes Prestasi . Yogyakarta: Pustaka Belajar.

Bruno, F.J. 2001. Stop Procrastinating. Jakarta: PT Gramedia Pustaka Utama.

Buku Wisuda Sarjana dan Pascasarjana periode II. 2010. Medan: Universitas Medan Area.

Chaplin, J.P. 2006. Kamus lengkap Psikologi. Jakarta: PT Raja Grafindo Persada.

Djamarah, S.B. 2002. Rahasia Sukses Belajar. Jakarta: Rineka Cipta. 
Ferrari, J. R. 1995. Procrastination and Task Avoidance, Theory, Research and Treathment. Journal. Available: www.proquest.com/procrastinators/ journal/uad/file/html. Tanggal Akses: 9 januari 2011

Forum Pendidikan Kesejahteraan Keluarga. 2007. Diantara Pilihan Akademik dan Organisasi. Universitas Pendidikan Indonesia. Available FTP: uad.ac.id. Tanggal Akses: 10 Desember 2010.

Glenn, D. 2002. Procrastination in College Student is a Maker for Unhealthy, Behaviors, Study Indiciates. The Chronicle of Higher Education.Journal. Available: http://phsyics.ohio-states.edu/procrastination/uc.id/html. Tanggal Akses: 11 januari 2011

Gufron, N.M. \& Rini R.S. 2010. Teori-Teori Psikologi. Yogyakarta: Ar-Ruzz Media.

Gufron, N.M. 2003. Hubungan Kontrol Diri dan Persepsi Remaja terhadap Penerapan Disiplin Orangtua dengan Prokrastinasi Akademik. Available FTP: demandiri.or.id/file/mnurgufron.pdf. Tanggal Akses: 12 Desember 2010.

Hadi, S. 2000. Metodologi Research, jilid 2. Yogyakarta: Andi Offset . 2004. Metodologi Research, jilid 3. Yogyakarta: Andi Offset

Holmes, R.A. 2000. The effect of Task Structure and Task Order on Subjective Distress and Dilatory Behavior in Academic Procrastinators. Journal. Available FTP: www.proquest.com/procrastinators. Tanggal Akses: 14 Desember 2010.

Larson, C.C. 1991. The Effect of a Cognitive-Behavioral Education Program on a Accademic Procrastination. Journal. Available FTP: www.proquest.com/procrastination. Tanggal Akses: 15 Desember 2010.

Lidya, C. 2008. Kecenderungan Prokrastinasi Berdasarkan Tipe Kepribadian. Available FTP http://library.gunadharma.ac.id/indeks-php=s1 fpsi. Tanggal Akses: 11 maret 2011

Muhammad, A. 2000. Komunikasi Organisasi. Jakarta: Bumi Aksara.

Hulu, P. S. 2010. Perbedaan Orientasi Locus of Control Antara Mahasiswa Yang Aktif Dengan Yang Tidak Aktif Berorganisasi di Universitas Medan Area. Skripsi. (Tidak Diterbitkan). Medan: Universitas Medan Area

Petunjuk Pelaksana/Pembinaan Organisasi Mahasiswa Universitas Medan Area.

Rizvi, A. 1998. Pusat kendali dan Efikasi Diri Sebagai Prediktor Terhadap Prokrastinasi Akademik Mahasiswa. Available FTP: http://library.gunadharma.ac.id/php=s1fpsi.pdf. Tanggal Akses: 12 Desember 2010.

Sentosa, M. 2008. Antara Orientasi Kuliah dan Orientasi Organisasi Mahasiswa. Jakarta: PT Gramedia Pustaka Utama.

Sulistianingsih, W. 2005. Kesiapan Bersekolah Ditinjau dari Jenis Penddidikan Prasekolah, Anak dan Tingkat Pendidikan Orangtua. Jurnal Psikologi. Volume I. No.1, 1-7. Jakarta: Fakultas Psikologi

Sumadi, S. 2000. Pengembangan Alat Ukur Psikologis. Yogyakarta: Pustaka Belajar.

Suparno. 2001. Membangun Kompetisi Belajar. Jakarta: Pustaka Belajar.

Widayanti, A. 2005. Perbedaan Interaksi Sosial Antara Mahasiswa S1 yang Mengikuti Organisasi Kemahasiswaan di Fakultas Psikologi Universitas Sumatera Utara. Skripsi. (Tidak Diterbitkan). Medan: Fakulas Psikologi Universitas Sumatera Utara

Winkel, W.S. 1997. Bimbingan dan Konseling di Institusi pendidikan. Edisi Revisi. Jakarta: PT Grasindo. 